\title{
PLANNING RURAL TOURISM DEVELOPMENT IN MACEDONIA
}

Biljana Petrevska, PhD,Assistant Professor, Faculty of Tourism and Business Logistics, Goce Delcev University Stip, Macedonia, e-mail: biljana.petrevska@ugd.edu.mk

Nikola V. Dimitrov, PhD,Assistant Professor, Faculty of Tourism and Business Logistics, Goce Delcev University - Stip, Macedonia, e-mail: nikola.dimitrov@ugd.edu.mk

\begin{abstract}
The paper attempts to emphasize the necessity of implementing planning process in tourism development, in particular to establishing preconditions for enhancing rural tourism. In this line, the research aims to highlight some stylized facts referring potentials for introducing rural tourism zones. For the purpose of the research, the case of Macedonia is analysed. The outcomes confirm modest results in tourism development. The paper contributes by identification of numerous potential rural tourism development zones, which may serve as a starting point in boosting modest upto-date tourism results in Macedonia.
\end{abstract}

Keywords: Tourism Planning; Rural Tourism; Development; Macedonia.

\section{Introduction}

The variety of changes in surrounding initiated creation of new ambient and challenges in front of all parties involved in tourism policy. This raised the issue of defining innovative presumptions and general directions for tourism development. In this regard, the necessity of implementing the planning process in tourism activity is introduced in order to provoke maximal contribution to economic development. So, one may argue the inevitable relationship between tourism, development and planning.

Namely, tourism hasemerged as a
major factor for economic
development.Regardless the nature, it has major
economic and social affects atregional and local
levels. So, some regions were highly positively
influenced by tourism impacts, like mainly
coastal (Emilia-Romagna in Italy), mountainous
(Valais in Switzerland), urban and historic (Ile-
de-Francein France) or regions with exceptional
natural resources (Quebec in Canada, Arizona
in the United States). Additionally, regions with

different profiles can also benefit from the growth of tourism. In this line, they can be rural, promoting green tourism, leisure and nature activities (Queensland in Australia), very remote, (Greenlandin Denmark) or regions undergoing industrial restructuring (Nord-Pasde-Calais in France).

The objective of this paper is to pose potentials for introducing rural tourism zones in Macedonia. The heterogeneous landscape, field configuration, natural resources as well as ethnography support the necessity of implementing planning process in introducing and developing rural tourism development.

\section{Literature review}

The issue of discussing the forth mentioned relationship is present in many studies. Some argue the conventional thinking (Stabler et al., 2010; Sharpley and Telfer, 2002), while othersfocus on local, place-based factors that influence tourism development (Raina and Agarwal, 2004). Likewise, a focus is put specifically on the less developed world and byarising many assumptions about the role of tourism in development and, in particular, highlighting the dilemmas faced by destinations seeking to achieve development through tourism (Huybers, 2007; Telfer and Sharpley, 2008). Some authors even endeavour a critical approach within a multi-disciplinary framework to relook at complex phenomenon of tourism development (Babu et al., 2008; Ramos and Jimènez, 2008). In the last twenty years, large regional differences in the quality of life haveemerged within many transition economies (Bartlett et al., 2010). Hence, much attention has beendirected to tourism's economic potential (Butler et al., 1998; Jenkins et al., 1998; Hall and Jenkins, 1998).Some authors underscore the significant opportunity for 
product development as a means to rural diversification (Bessière, 1998). Others examine the contemporary issues and reasons for tourism development as a strategy for urban revitalization (Pearce and Butler, 2002) as well as for providing the basis for better informed integration of tourism in regional development strategies (Sharma, 2004). Moreover, some discussions are towards various policy innovations as activities by regions in terms of tourism development considering continuousgrowth within the sector (Giaoutzi and Nijkamp, 2006). Additionally, as tourism and regional development are closely linked, regions and local authoritiesplay a key role in formulating policy and organizingtourism development(Constantin, 2000).

Over the past decades, the rural tourism became very popular and currently has strong advantages on the international market. This is particularly important since rural tourism has already played a key role in development of some rural zones that were economically and socially depressed (Blaine and Golan, 1993; Chuang, 2010; Dernoi, 1991; Hall and Richards, 2002; Ploegand Renting, 2000; Ploeg et al. 2000; Roberts and Hall, 2001; Simpson, 2008).

There is a relatively large body of literature of local academicians and practitioners dealing the issue of rural tourism in Macedonia. In this respect, different approaches and attitudes may be observed resulting with territorial division into regions, counties, zones and local areas (Dimitrov and Petrevska, 2012; Jeremic, 1971; Marinoski, 1998; Panov, 1972; Stojmilov, 1993). Yet, only few of them underline the necessity of introducing the planning process to tourism flows (Petrevska, 2011) in the line of enhancing modest development and creating preconditions for further advanced promotion (Petrevska and Koceski, 2013).

\section{Necessity of tourism planning}

Planning tourism development can trigger general economicgrowth by creating a new dynamic. It can also contribute to better land use planning by countering rapidurbanisation in developed countries and by attracting populations to new regions where tourism isdeveloping. However, some guidelines for planning and development must be laid down in order to preserve resources, ensurecomplementarity between areas and define tourism poles. Yet, planning tourism developmentin the underdeveloped areas enables development of the periphery, retainingthe population in the homeland, infrastructure is improved as well asall other activities which contribute toprosperity of the regionand a country.

Namely, tourism policy must be created in a way that ensures hosting visitors by maximizing the benefits to stakeholders, while minimizing the negative effects, costs, and impacts associated with accomplishing successful destination (Goeldner and Ritchie, 2006). In this respect, all efforts in order to consider and understand the interrelated nature of tourism industry require monitoring and evaluation when tourism policy issues are involved (Edgell et al., 2008). However, many case studies on planning provide indications that tourism policy may be viewed as simple by those whose job is to create and implement it (Wilkinson, 1997).

Due to the fact that tourism generates many impacts which are contributing to overall economic development, the inevitable connection is evident to the process of state, regional and community planning. In the same line, it is important to create a strategic document for tourism development as a strong mechanism in assessing the development priorities (Frechtling, 2001; Gunn, 1993; Hall, 2005; Williams and Shaw, 1991).

In order to accomplish the projected economic targets, each government must define its role in undertaking operative measures and activities. Everyday practice has justified the state intervention in tourism industry regardless the size and effects. However, the overall state intervention usually does not provoke fully positive impacts on tourism development. On the other hand, the absence of governmental intervention in free market economy may lead to short-term benefits in tourism oriented enterprises, so the lack of a long-term control over tourism supply may occur. Therefore, the 
necessity of a balanced state approach in terms of tourism intervention is a must. So, the government may serve as balance between the exploratory power of private tourism enterprises on one hand, and its own interests, on the other. In this line, it must have been preciouses since the basic goals of the government and the basic goals of the enterprises may not intersect always, although having common interests in most cases.

Accordingly, the partial state intervention is identified as the best solution ever, despite the cognitive conclusion that this kind of "mixed" entrepreneurship often initiates strategic conflicts among the state and the private enterprises. In this respect, the preliminary task is to identify the priority areas of state intervention as the only way of making it the most effective. The government may not be directly involved in tourism support, except in some areas of national importance such as developing tourism information systems or national tourism promotion. Moreover, the government may initiate actions and activities for tourism development by ensuring funds or setting quality standards. Hence, this kind of intervention is acceptable as a supportive and balance-oriented concept. Therefore, the role of the government is to act as an economic power that will guide and manage tourism development. Its intervention is justified only when tourism by itself may not act efficiently.

\section{Current rural tourism status in Macedonia}

The up-to-date results point that Macedonia, opposite many tourism-oriented countries, notes very modest results in tourism, particularly to rural tourism. Although there is a strategic document for this issue, the rural tourism potentials in Macedonia are still insufficiently exploited (Government of Macedonia, 2009). In this regards, it is necessary that rural tourism must have significant position in regional programs and national development strategy being defined as key opportunity for economic development.

Consequently, just recently a National Strategy for rural tourism was adopted covering a five-year horizon from 2012 until 2017 (Government of Macedonia, 2012). This document addresses various approaches in the line of strengthening rural tourism in Macedonia.

\section{Rural tourism potentials in Macedonia}

Based on field-research, the knowledge of geographic and socio-ethnographic landscape of Macedonia supplemented by institutional framework given in the national strategy for rural development, the authors illustrate rural tourism potentials in Macedonia (Fig. 1). In this respect, Fig 1 poses an overview of thirty rural tourism development zones spread over entire territory of Macedonia. It is noticeable that the size of rural tourism zones differs in a quite manner. The bigger the circle, the larger territorial dispersion. So, the rural tourism development zone of Mariovo (No.14)is the largest one encountering only six rural settlements that practice rural tourism versus more than thirty-three rural settlements that are rich on potentials for developing rural tourism. 


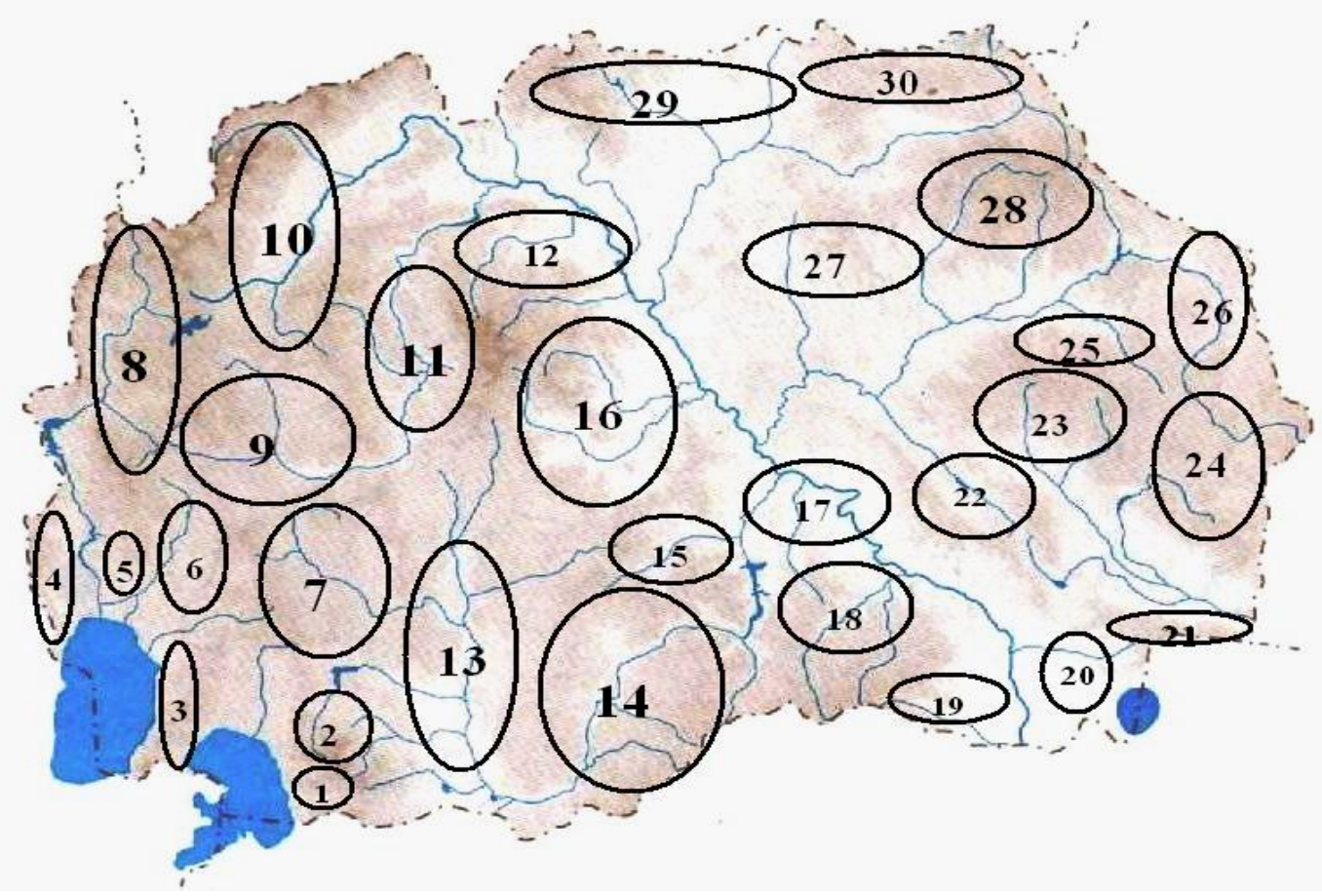

Fig. 1. Rural tourism development zones in Macedonia

Source: Dimitrov and Petrevska (2012:160).

The research outcomes point to valuable fact that forty rural municipalities in Macedonia have substantial background for developing rural tourism by using their facilities for accommodation, catering, tracking paths and sightseeing. Moreover, all of them unconditionally have catering resources and opportunity for including sightseeing as main preconditions for rural tourism development. Yet, poor infrastructure in terms of pathways is a limiting factor supplemented by lack of institutional support and adequate policy.

So, one may argue that rural tourism in Macedonia has initial potentials for emerging as major factor for economic development by spreading economic and social impacts at regional and local levels, particularly in areas where rural tourism activities take place.

\section{Conclusion}

The research outcome identifies that rural tourism must have a significant position in regional programs and national development strategy being defined as a key opportunity for economic development. The outcomes underline that Macedonia, opposite many tourism-oriented countries, notes very modest results in this area. Furthermore, the research allows increased understanding of the way rural tourism operates in Macedonia.

As general conclusion one may note the necessary of undertaking serious measures and activities on central level, and local as well. Macedonian tourism suffers from lack of coordinated activities and organizational forms functioning on horizontal and vertical line, unclear set of goals, aims and field of interest within the public, as well as the private tourism sector. The result is a poorly developed tourism industry. Therefore, as a starting point, partial tourist products must be introduced until the moment when certain preconditions are created in a sense of strengthening the cooperation between all key actors in tourism. Hence, it can be concluded the need for further governmental intervention in tourism in Macedonia, with emphasize to be supportive and balanced since up-to-date effects are positive, but very modest.

Moreover, the modest up-to-date results in this area, urges the need for identifying 
effective strategic framework for enhancing rural tourism. Finally, the paper strongly supports fulfilment of planning process in rural tourism development in Macedonia, particularly by introduction of around thirty rural tourism development zones.

\section{References}

1. Babu, S. S., Mishra, S.\&Parida, B. B. (2008).Tourism development revisited: concepts, issues and paradigms. Saga Pubns.

2. Bartlett, W., Cipusheva, H., Nikolov, M. \& Shukarov, M. (2010). The quality of life and regional development in FYR Macedonia.Croatian Economic Survey, 12(1): 121-162.

3. Bessière, J. (1998). Local development and heritage: traditional food and cuisine as tourist attractions in rural areas. Sociologia Ruralis, 38 (1): 21-34.

4. Blaine, T. and Golan, M. (1993). Demand for Rural Tourism: AnExploratory Study. Annals of Tourism Research, 20: 770773.

5. Butler, R. Hall, C. M.\& Jenkins, J. M. (1998). Tourism and recreation in rural areas. John Wiley \& Sons, Chichester.

6. Constantin, D. (2000).Tourism and Environmentally Sustainable RegionalDevelopment: The Case of Romania. 40th Congress of the EuropeanRegional Science Association, 29 August-1 Sept 2000.

7. Chuang, S. T. (2010). Rural tourism: perspectives from social exchange theory, Social Behavior and Personality.38(10): 13131322.

8. Dernoi, I. (1991). About Rural and Farm Tourism. Tourism recreationresearch, 16(1): 3-6.

9. Dimitrov, N. \& Petrevska, B. (2012). Rural tourism development zones: the case of Macedonia.Researches review of the Department of geography, tourism and hotel management, 41: 152-162.

10. Edgell, D. L., Del Mastro, A. M., Smith, G. \& Swanson, J. R. (2008).Tourism Policy and Planning: Yesterday, Today and Tomorrow. Elsevier.

11. Frechtling, D. C. (2001).Forecasting Tourism Demand: Methods and Strategies, Butterworth - Heinemann.

12. Goeldner, C. R. \& Ritchie, J. R. B. (2006).Tourism: Principles, Practices, Philosophies. John Wiley \& Sons Inc., New Jersey.
13. Government of the Republic of Macedonia, Ministry of Economy (2009). National Strategy for tourism development 2009-2013, Skopje.

14. Government of the Republic of Macedonia, Ministry of Economy (2012). National Strategy for rural tourism 2012-2017, Skopje.

15. Giaoutzi, M. \& Nijkamp, P. (2006).Tourism and regional development new pathways. Ashgate Publishing, Ltd.

16. Gunn, C. A. (1993).Tourism Planning Basics, Concepts, Cases, Taylor\&Francis.

17. Hall, C.M. \& Jenkins, J.M. (1998).“The Policy Dimensions of Rural Tourism and Recreation”. In: Butler, R. et al. (eds.), Tourism and Recreation in Rural Areas, John Wiley\&Sons, pp.: 19-42.

18. Hall, D. and Richards, G. (2002). Tourism and sustainable community development, London.

19. Hall, M. C. (2005). The Future of Tourism Research. In: Ritchie, B. (Ed.) Tourism Research Methods: Integrating Theory with Practice, CABI Publishing, pp.: 221-231.

20. Huybers, T. (2007).Tourism and developing countries. Edward Elgar Publishing.

21. Jenkins, J., Hall, C.M. \& Troughton, M. (1998): "The restructuring of rural economies: rural tourism and recreation as a government response”. In: Butler, R., Hall, C.M., Jenkins, J. (eds.), Tourism and Recreation in Rural Areas, John Wiley \& Sons, pp.: 43-68.

22. Jeremic, D. (1971). Tourism regions in Macedonia (in Macedonian), Skopje.

23. Marinoski, N. (1998). Tourism geography of Macedonia (in Macedonian), FTU, Ohrid.

24. Panov, M. (1972). Tourism geography with tourism basics (in Macedonian) Turisticka geografija so osnovi na turizmot, FTU Ohrid.

25. Pearce, D. \& Butler, R. (2002).Contemporary issues in tourism development. Routlege.

26. Petrevska, B. (2011). Economic Planning of Tourism Demand in Macedonia.Economic Development, 3/2010: 133-145.

27. Petrevska, B. \& Koceski, S. (2013). Recommending Ideal Holiday at National Level.Journal of Applied Economics and Business, 1(1): 15-22.

28. Ploeg, J. D.\&Renting, H. (2000). Impact and potential: A comparative Review 
ofEuropean Rural DevelopmentPractice. Sociologia ruralis 40(4): 529-543.

29. Ploeg, J.D., Renting, H., Bruner, G., Knickel, K., Manion, J., Marsden, T., Roest, D. K., Sevilla-Guyman, E.\&Ventura, F. (2000). Rural Development: From Practices and Policies towards Theory. Sociologia ruralis40(4): 391-408.

30. Raina, A. K. \& Agarwal, S. K. (2004).The essence of tourism development: dynamics, philosophy and strategies, Sarup \& Sons.

31. Ramos, A. D. \& Jimènez, P. S. (2008).Tourism development: economics, management and strategy. Nova Science Pub.

32. Roberts, L. and Hall, D. (2001). Rural Tourism and Recreation:Principles to Practice. CABI Publishing:Wallingford.

33. Stojmilov, A. (1993). Tourism geography (in Macedonian), Skopje.
34. Simpson, M. C. (2008). Community benefit, tourism initiative: A conceptual oxymoron. Tourism Management, 29: 1-18.

35. Stabler, M., Papatheodorou, A. \& Sinclair, T. M. (2010).The economics of tourism. Taylor \& Francis.

36. Sharpley, R. \& Telfer, D. J. (2002).Tourism and development: concepts and issues. Channel View Publications.

37. Sharma, K. K. (2004).Tourism and regional development, Sarup \& Sons.

38. Telfer, D. J. \& Sharpley, R. (2008).Tourism and development in the developing world. Taylor \& Francis.

39. Wilkinson, P. (1997).Tourism Planning on Islands. New York, Cognizant Communications.

40. Williams, A. \& Shaw, G. (1991).Tourism and Economic Development, Belhaven Press. 